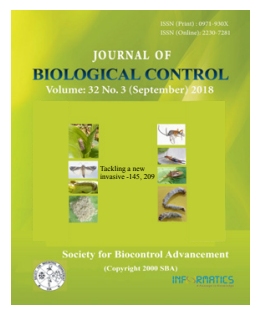

Research Article

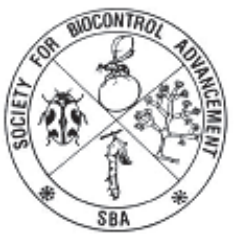

\title{
Pithy stems - An effective and viable option to conserve sub social and solitary bees and wasps
}

\author{
U. AMALA*, TIMLAPUR M. SHIVALINGASWAMY and M. PRATHEEPA \\ Division of Insect Ecology, ICAR - National Bureau of Agricultural Insect Resources (NBAIR), H.A Farm Post, PB No 2491, \\ Bellary Road, Bangalore - 560024, Karnataka, India \\ "Corresponding author E-mail: amala.udayakumar@icar.gov.in
}

\begin{abstract}
Artificial trap nesting of bees will help in their conservation in situ and utilizing them for enhancing pollination service in cropping systems. The present study was undertaken to study the nesting behavior and rate of acceptance of pithy stems for nesting by the different bee species at ICAR-NBAIR Yelahanka Campus (13.096792N, 77.565976E). Fifteen nests comprising of pithy stems of Caesalpinia pulcherrima each made into three bundles containing five nests each were placed at three places in two sites viz., Site 1 (Pollinator Garden) and Site 2 (Vegetable block). The days taken by the bees to accept the trap nests placed in the pollinator garden and vegetable field were found to be 5.87 and 11.53 days with a percent acceptance of 80 and 66.67 per cent, respectively. The average number of cells built by the bees in the nests obtained from the pollinator garden and vegetable ecosystem were found to be 6.00 and 5.33 respectively. Ceratina binghami, C. hieroglyphica, Megachile lerma and predatory sphecid wasps were found to emerge out from the trap nests. Diversity of the stem nesting bees was found to be higher in the nests placed in the pollinator garden as compared to vegetable block.
\end{abstract}

KEY WORDS: Ceratina binghami, conservation, diversity, evenness, pithy stems, richness

(Article chronicle: Received: 18-04-2018; Revised: 11-08-2018; Accepted: 15-09-2018)

\section{INTRODUCTION}

Bees of the subfamily Xylocopinae and Megachilinae construct their nests in the pre-existing cavities, hollow pithy stems, dead woods and manmade holes on various substrates (Bosch et al., 2001; Cane et al., 2007). The pollination services provided by the bees were at a decline as a result of various anthropogenic activities that interfere with the bee foraging and nesting activity (Biesmeijer et al., 2006; Potts et al., 2010). There is an immense need to conserve these bees for the valuable ecosystem service provided by them. Utilization of pithy stems is an efficient way to attract the small carpenter, leaf cutter and certain solitary wasps. Pruning trees and shrubs leave a hollow pithy core that serves as a substrate for the twig nesting bees to construct their nests. Trap nests as an efficient way to monitor populations of bees in different habitats (Strickler et al., 1996). The present study was undertaken to investigate the rate of acceptance of pithy stems by the stem nesting bees placed at two different habitats and to study the diversity of insects that constructed their nests in the pithy trap nests.

\section{MATERIALS AND METHODS}

Fifteen nests comprising of pithy stems of Caesalpinia pulcherrima each made into three bundles containing five nests each were placed at three places in two sites viz., Site 1 (Pollinator Garden) and Site 2 (Vegetable block) in the experimental farm of ICAR-National Bureau of Agricultural Insect Resources (NBAIR), Bengaluru Yelahanka Campus (13.096792N, 77.565976E). The nests were observed regularly on day-to day basis for the signs of acceptance by the bees. The presence of entrance hole in the ends of the pithy stem was considered as the indication of acceptance of the nest by the bees. The accepted nests were collected regularly and brought to the laboratory for further studies. The number of days taken by the bees to accept trap nest, number of cells formed inside each nest, number of adult bees emerged out from the nests were observed and recorded. The collected nests were observed for signs of parasitization and emergence of any parasites.

\section{Data analysis}

The percent acceptance of the nests by the bees in the two different habitats viz., pollinator garden and vegetable ecosystem was worked out. The biodiversity indices were calculated using the PAST Software. Shannon Weiner diversity index, takes into account the number of individuals as well as number of taxa indicated by $\mathrm{H}=-\operatorname{sum}\left(\left(\mathrm{n}_{\mathrm{i}} / \mathrm{n}\right) \ln \left(\mathrm{n}_{\mathrm{i}} / \mathrm{n}\right)\right)$ where $n_{i}$ is number of individuals of taxon ' $i$ '. Margalef's richness index: $(S-1) / \ln (n)$, where $S$ is the number of taxa, and $n$ is the 
number of individuals. Evenness index is calculated using the formula $e^{\mathrm{H}} / S$ where $\mathrm{H}$ indicates the Shannon Weiner index and $\mathrm{S}$ is the number of taxa. The Berger-Parker Index (d) gives an idea of about the most dominant species of insect when several species visit the particular nest and is calculated using the formula $\mathrm{d}=\mathrm{N}_{\max } / \mathrm{N}$ where $\mathrm{N}_{\max }$ is the highest number of individuals represented by a species and $\mathrm{N}$ is the total number of individuals in a sample.

\section{RESULTS AND DISCUSSION}

The nest acceptance rate of the bees and other insects diversity of the bees trapped in the nests placed in the two different habitats were presented in Table 1 and 2. The days taken by the bees to accept the trap nests placed in the pollinator garden and vegetable field were found to be 5.87 and 11.53 days with a percent acceptance of 80 and 66.67 percent respectively. The average number of cells built by the bees in the nests obtained from the pollinator garden and vegetable ecosystem were found to be 6.00 and 5.33 respectively. The Shannon Weiner diversity of the insects trapped in the pithy trap nest placed in the pollinator garden (1.10) was found to relatively higher compare to the trap nest placed at vegetable ecosystem (1.06). Species richness is the number of species found in a community or ecosystem (Zhang et al., 2012). Species richness index was found to be higher in the trap nests placed in the pollinator garden compared to the nests placed at the vegetable ecosystem. Four insect species, Ceratina binghami, C. hieroglyphica, Megachile sp. and
Sphecid wasps were found to emerge out from the trap nest placed in the pollinator garden. C. binghami, C. hieroglyphica and Megachile sp. were found to emerge out from the nests placed in the vegetable ecosystem. More number of sphecid wasps was found to emerge out from the trap nests laced in the vegetable ecosystem.

With respect to nest abundance (number of nest occupied), it was found to be higher in pollinator garden $(n=90)$ and relatively lesser in vegetable ecosystem $(n=44)$. The most abundant species to occupy the nest was found to be Ceratina binghami (56.67\%) followed by C. hieroglyphica (24.44\%), Megachile sp. (11.11\%) and Sphecids (7.78\%). No signs of parasitization were observed in the trap nests. McIntosh (1996) reported that small carpenter bee, Ceratina nanula preferred Sambucus twigs but of different diameters for nesting. The dominance index was found to be higher in the trap nests placed in the pollinator garden $(0.567)$ compared to the vegetable ecosystem (0.454). The higher dominance index and diversity index in the pollinator garden might be due to availability of diverse flowering plants unlike the vegetable ecosystem. The diverse flowering plants with continuous availability of pollen would have supported more bee species in their nesting unlike uniformly sown monocropped vegetable ecosystem. Habitat with diverse vegetation obviously supplies a greater amount of nutritious pollen, thereby supporting more bee species (Gathmann et al., 1994). Similar observations were recorded by Buschini (2006) who reported that the abundance and diversity of bees

Table 1. Number of trap-nesting bee species and their nest abundance in two habitats

\begin{tabular}{|l|c|c|}
\hline \multirow{2}{*}{\multicolumn{1}{c|}{ Species }} & \multicolumn{2}{c|}{ Habitats } \\
\cline { 2 - 3 } & Pollinator Garden & Vegetable ecosystem \\
\hline Species number & 4 & 3 \\
\hline No of days taken to accept the nest & 5.87 & 11.53 \\
\hline Percent acceptance of nest & 80 & 66.67 \\
\hline No of Ceratina binghami & 51 & 12 \\
\hline No of Sphecids wasps & 7 & 20 \\
\hline No of Ceratina hieroglyphica & 22 & 0 \\
\hline No of Megachilids & 10 & 12 \\
\hline
\end{tabular}

Table 2. Diversity indices of the trap nesting bees in two habitats

\begin{tabular}{|l|c|c|c|c|}
\hline \multicolumn{1}{|c|}{ Habitats } & Shannon index H' & Margalef's richness index $\mathrm{D}_{\mathrm{Mg}}$ & Evenness J' & Berger-Parker dominance \\
\hline Pollinator Garden & 1.109 & 0.667 & 0.757 & 0.567 \\
\hline Vegetable ecosystem & 1.067 & 0.528 & 0.969 & 0.454 \\
\hline
\end{tabular}


was found to be higher in swamp habitat with more floral resources compared to grassland habitats.

The results of the study suggested that, the stem nesting bees readily accept the stems of Caesalpinia for nesting. These pithy stems could be used to enhance the number of bees in the cropping environment for their pollination service. These trap nests are cheaper and effective to conserve the stem nesting bees.

\section{REFERENCES}

Biesmeijer JC, Roberts SPM, Reemer M, Ohlemuller R, Edwards M, Peeters T. 2006. Parallel declines in pollinators and insect-pollinated plants in Britain and the Netherlands. Science 313: 351-354. https://doi. org/10.1126/science.1127863 PMid:16857940

Bosch J, Maeta Y, Rust R. 2001. A phylogenetic analysis of nesting behavior in the genus Osmia (Hymenoptera: Megachilidae). Ann Entomol Soc Am. 94: 617-627. https://doi.org/10.1603/0013-8746(2001)094[0617:APA ONB]2.0.CO;2

BuschiniMLT.2005. Species diversityandcommunity structure in trap-nesting bees in Southern Brazil. Apidologie 37: 58-66 https://doi.org/10.1051/apido:2005059

Cane JH, Griswold T, Parker FD. 2007. Substrates and materials used for nesting by North American Osmia Bees (Hymenoptera: Apiformes: Megachilidae). Ann Entomol Soc Am. 100(3): 350-358. https://doi.
org/10.1603/0013-8746(2007)100[350:SAMUFN]2.0 $\mathrm{CO} ; 2$

Gathmann A, Greiler HJ, Tscharntke T. 1994. Trap nesting bees and wasps colonizing set-aside fields: succession and body size, management by cutting and sowing. Oecologia 98: 8-14. https://doi.org/10.1007/ BF00326084 PMid:28312790

McIntosh M. 1996. Nest-Substrate preferences of the twignesters Ceratina acantha, Ceratina nanula (Apidae) and Pemphredon lethifer (Sphecidae). J Kansas Entomol Soc. 69(4): 216-231.

Potts SG, Biesmeijer JC, Kremen C, Neumann P, Schweiger O, Kunin WE. 2010. Global pollinator declines: Trends, impacts and drivers. Tree 25: 345-353. https://doi. org/10.1016/j.tree.2010.01.007 PMid:20188434

Strickler K., Scott VL, Fischer RL. 1996. Comparative nesting ecology of two sympatric leafcutting bees that differ in body size (Hymenoptera: Megachilidae). $J$ Kans Entomol Soc. 69: 26-44.

Zhang H, John R, Peng Z, Yuan J, Chu C, Du G, Zhou S. 2012. The relationship between species richness and evenness in plant communities along a successional gradient: A study from sub-alpine meadows of the Eastern QinghaiTibetan Plateau, China. PLoS One 7(11): 49024. https:// doi.org/10.1371/journal.pone.0049024 PMid:23152845 PMCid:PMC3494667 